\title{
28 Research Square \\ The authors have requested that this preprint be removed from Research Square.
}

Keywords:

Posted Date: April 1st, 2021

DOI: https://doi.org/10.21203/rs.3.rs-362458/v1

License: (c) (i) This work is licensed under a Creative Commons Attribution 4.0 International License.

Read Full License 


\section{Abstract}

The authors have requested that this preprint be removed from Research Square. 